\title{
Decolonizing Language Teachers' Teaching Practices through a Postmethod Pedagogy ${ }^{1}$
}

\section{Descolonización de las prácticas docentes de los profesores de idiomas a través de una pedagogía post-método}

\author{
Adriana Milena Avella Alvarado ${ }^{2}$ \\ nanita_avella@hotmail.com \\ Fundación Universitaria Juan de Castellanos \\ Geidy Yohana León Lozada ${ }^{3}$ \\ leonyohana20@hotmail.com \\ I.E. San Jerónimo Emiliani
}

Received: August 10, 2015

Accepted: November 18, 2015

How to cite this article (APA, 6th ed.): Avella, A., León, G. (2016) Decolonizing Language Teachers' Teaching Practices through a Postmethod Pedagogy. Enletawa Journal, 9 (1), 69-85

\begin{abstract}
This article presents a critical and theoretical reflection upon a pedagogical proposal which considers an EFL teaching practice. The target pedagogical experience relies on the first step to starting decolonizing language teachers' teaching practices in the context they live in. Understanding that decolonizing teaching practices is a continuous process of reflection that involves decisionmaking, awareness of the students' needs, and the context in which they are

1 The article is classified as a reflective paper. This article is the result of the seminar of Sociolinguistics.

2 She works as an English Language teacher at Fundación Universitaria Juan de Castellanos. She holds a B.A in Modern Languages from Uptc. She is currently a M.A Candidate in the Language Teaching Program at the same University. Her research interests rely on evaluation and formative assessment practices.

3 She works as an English teacher and directs the technical projects at I.E San Jerónimo Emiliani en Tunja. She holds a B.A in Modern Languages English- Spanish from Universidad Peagógica y Tecnológica de Colombia. she is currently a M.A Candidate in the Language Teaching Program at the same University. Her research interests are: Learning Environments, fostering reflection and critical thinking, foreign language learning and teaching and students as researchers.
\end{abstract}


immersed. Firstly, the document will present some of the authors' insights about language policies as the National Bilingual Program (PNB). Secondly, the manuscript addresses the teaching approach in which the proposed activities are embedded as a means to stress the necessity to start decolonizing pedagogical practices. Thirdly, the manuscript delves into Kumaravadivelu's particular perspectives of Method and Post method pedagogy in language teaching. Finally, there will be some reflections about what language teachers do for engaging students in their own language learning providing meaningful practices, and what they have constructed about decolonization.

Key words: Foreign Language Teaching, Local Knowledge, Particularity, Possibility and Practicality.

\section{Resumen}

Este artículo presenta una reflexión teórico-crítica de una propuesta pedagógica que considera una práctica de enseñanzas de inglés como lengua extranjera, la cual muestra el primer paso para empezar a descolonizar prácticas de enseñanza en el contexto en el que viven los docentes. Una práctica descolonizadora es un proceso continuo de reflexión que implica toma de decisiones, conocimiento de las necesidades de los estudiantes y del contexto en el cual estos están inmersos. El documento presentará primero algunas percepciones sobre las políticas del Plan Nacional de Bilingüismo (PNB) desde las perspectivas de los autores como docentes de inglés. Segundo, el método de enseñanza sobre el cual las actividades propuestas se presentan se discute. Tercero, perspectivas de Kumaravadivelu sobre el método y el post método son integradas. Finalmente, se presentarán algunas conclusiones sobre lo que los docentes de lengua hacen para involucrar a los estudiantes en su propio aprendizaje de inglés.

Palabras clave: Enseñanza de una lengua extranjera, Conocimiento local, Particularidad, Posibilidad y Practicabilidad. 


\section{Introduction}

Bearing in mind that the implementation of different educational policies based on foreign models such as the Basic standards in Foreign Languages Competences (English) (Estándares básicos de competencias en lenguas extranjeras) (inglés) and the Common European framework have become a reality that makes us reflect as languages teachers on the intentions and EFL perspectives the government might have for the creation of language programs, this paper addresses a constant challenge: "how to build options when programs do not consider individual differences at the local, regional and national levels". While policies tried to convince teachers with a discourse of improvement and quality about the advantages to teach and to assess students through international criteria and the "advantages "to provide the same opportunities to learners in language teaching and learning processes, the Minister does not consider basic conditions for instance culture, local knowledge, students' learning needs, and teachers' backgrounds to achieve that ambitious goal.

Sánchez (2013) claims that "in spite of having the Bilingualism program in Colombia the educational sector has huge challenges to fulfill the bilingualism ideal levels (SpanishEnglish), in particular in what refers to the offer of qualified English language teachers" (p.5). Local knowledge should be an important and determinant aspect to define what language educators should teach students in English language classes. Additionally, it is relevant that teachers acknowledge their responsibility on creating in students the desire for learning English and make it an important resource to respond to their real urgency for communication.

To being with it is important to understand that what the MEN proposes to develop in terms of Colombia bilingual: "the communicative competences improvement in English as a Foreign language in all educational sectors" (Programa Nacional de Bilinguismo Colombia 20042019, p. 4), does not align with what the Educational condition in Colombia is. What supports the previous claim refers first, to the fact that in some cases non-English language teachers teach English. Second according to the (MEN, 2011 as cited in Sánchez 2013), the demand coming from the educational sector for options to educate students in English is higher than what can actually be offered. Thus, there are not enough possibilities to become bilingual or to develop the communicative competences in English; there are not enough English teachers to cover all the Colombian institutions.

Programs like "Teaching in Foreign Languages- the challenge" (Formar en lenguas extranjeras- el reto, 2009) and nowadays, "Bilingual Colombia", (Colombia Bilingue) do not belong to 
what Colombian people's educational situations entail, neither they take into consideration students' reality, background, and culture. Therefore, most English teachers are concerned about what being or becoming bilingual in Colombia refers to, or in the case of the Colombian government, they wonder about what the government knows and understands about second language learning in our country, and the conditions in which students and teachers have to conduct their practices.

Mckay (2003) sates that one of the problems when dealing with English language teaching is using the native speaker model as the final goal for English learning (p. 45). In this perspective, language teachers, institutions and students need to consider English learning as a way to recognize their own culture to start decolonizing teaching and learning practices. These pedagogical practices are usually supported upon a set of contents divergent from the reality and interests that guide students and language teachers. That is to say, schools should incorporate students' own culture, context and local knowledge into the institutions' curriculum to support meaningful learning.

In this perspective, it becomes relevant to understand teaching through a post method pedagogy. Kumaravadivelu explains that "the post method condition empowers practitioners to construct personal theories of practice" (p. 33). A post-method pedagogy allows teachers to go beyond practice, being sensitive to students' realities and pursuing local goals that respond to specific circumstances.

Additionally, the English language has become a worldwide language and many people have diverse purposes for learning it. Some learners are interested in it for business, for others is a requirement, some others learn it because it is part of the curriculum at primary or secondary school, or just at a university level, and others want to acquire it because it represents any opportunity to work or just to teach it. In the case of the context for which this proposal was created, there is certain kind of local resistance in regards to English learning because parents and students do not consider it as an essential subject which will have a significant impact in their future development. This might be related to the kind of topics included in textbooks. These issues do not align with the real necessity and the importance learners might have to communicate in another language. The more teachers become involved in the context where their students live and they engage with their pupils' language and cultural manifestations, ideology and dreams, the more their decisions will be the right ones to conduct meaningful teaching and learning process. 


\section{Language view considerations}

On one hand, the traditional view of language considers that learning a language is a matter of mastering its grammatical system in which the "well written and spoken forms of language" are privileged. However, more than managing a linguistic knowledge, learning a language implies an un-derstanding that through language people establish relationships with others, acquire and share knowledge, express their thoughts and feelings, create their identity and recognize their culture and someone else's culture too. According to Halliday (1979) humans are individuals and social beings that establish different kinds of relationships with their peers through language.

Therefore, language intervenes in the process through which a human being becomes a social human being. It has an essential function as the main channel to show different life models that teach a person how to act as a member of a society. It does not happen as a result of instruction, but instead through the accumulation of experiences of the human being as a social member. In this case, Kumaravadivelu (2006) "sees language teaching as a prime source for sensitizing learners to social inequalities that control them, and for developing necessary capabilities for addressing those inequalities" (p 15). Hence, language learning is seen as a response to social interactions in order to address social issues of informing, suggesting or requesting what each learner considers in terms of his/her communication.

Subsequently, language functions as a bridge for people's interactions in knowledge construction. Language is a way of identity, who I am and who you are, and the way both of us use language to pursue communicative purposes. Language and learning occurs through interaction as constructivism and socioconstructivism theories state, humans generate knowledge and meaning from an interaction between their experiences and ideas; Knowledge is built in response to interactions with environmental stimulus.

On the other hand, language can be also seen as a means of power and domination. The ideological power behind language influences people in two main aspects: First, peoplecan create perspectives of the world according to others' points of view and second, they try to convince others or to impose personal beliefs and thoughts through language. Therefore, it is necessary to refine teaching language objectives with the aim of creating opportunities to increase students' awareness about the hidden implications of learning a second language.

Subsequently, in the case of learning and teaching the concept of language may differ according to the purposes each person has to use it; for instance, for getting communicative purposes; for understanding language as a whole system of semantic, phonological, syntactic or grammar patterns, or just 
for defining the use of language as users' determinations. That is to say, language works depending upon the context. Kumaravadilevu (2006) defines language in three different ways: "Language as a system", "language" as discourse", and "language as ideology". Regarding "language as system", he states that "each unit of language, from a single sound to a complex word to a large text-spoken or written-has a character of its own, and each is, in some principled way, delimited by and dependent upon its co-occurring units" (p.4). Accordingly, language is a process of knowledge construction which starts with small pieces of information to finally construct bigger meanings.

Hallyday (as cited in Kumaravadivelu, 2006) describes language as discourse; as follows: "language communication is the product or the result of the process of interplay between the ideational, interpersonal and textual functions of language" (p 8). In this sense, language is the consequence of social interactions that convey meanings among diverse contexts. "As the child interacts with language users, he or she begins to understand the potential meaning within the language, and develops a capacity to use it" (Kumaravadivelu, 2002).

Kroskrity (2000) says that "language ideologies represent the perception of language and discourse that is constructed in the interests of a specific social or cultural group" (p. 8). Therefore, it is important to mention that meaning is constructed through language interaction and the way a language user perceives it. In this regards, Carvajal (2011) states that "... Culture plays an important role to construct meaning, analyze discourse and use language meaningfully" (p. 81). Hence, Language is a tool for negotiating meaning, adopting certain positions of consciousness about the use of it and what people can achieve through it depending on peoples' backgrounds, and the spaces for communication in which language takes place.

\section{Importance of language teachers' local knowledge in a post method pedagogy}

Post method pedagogy relies on the fact that language teachers can take advantage of their teaching experiences to construct their own theory, and improve their own teaching practices as a means to work through their own contexts and their own students' realities. Since usually language teachers know their students' realness and their communicative language needs, they have the power to decide what can or cannot work in students' language learning. Post method pedagogy also makes language teachers aware of recognizing the existence of more than one method to pursuit language teaching and learning goals. Hence, language teachers, and bilingual programs must assume a critical and reflective position regarding the theory 
and practice, considering that theory is usually divorce from what really occurs in language teaching and learning processes.

A crucial aspect when adopting a critical approach to language teaching is to be aware of the power and political forces behind educational policies, but also the need to transform these realities through teachers' own practices. Teachers need to understand that they are not theory consumers. They can assume a critical point of view about the educational policies they are implementing and feel confident about building their own principles of teaching, learning, and educational policies that can be constructed based on their experiences, their professional knowledge and the context where they are immersed. In addition, they can create their own perspectives making informed decisions based on their professional knowledge, their everyday practices and the role they have in language teaching.

Teachers are intellectuals with a wide background of teaching and learning knowledge which allows them to project how to conduct their practices. However, this is not enough to guarantee an effective and pertinent learning process that fulfills the expectations of the community, students, school, governmental policies as well as their own. Therefore, it is required that teachers have direct contact with the context they work with. They need to know their students, understand and consider their needs and characteristics and feel able to make their own decisions based on theory as a way to know what functions or not in a given context, with special conditions, in different situations. Freire and Faundez (2013) explain that to apply a concept is valid if it allows understanding and transformation of the reality. He states that:

The intellectual must follow the inverse way: to start from the reality, from the daily action of the community and ourselves, since, we are immersed in daily experiences, to reflect in the daily action and only then, to create ideas to comprehend it. And those ideas would not be model ideas anymore but they will be made based on reality (p. 62).

On the other hand, according to Kumaravadivelu (2003), teachers can develop three main roles. They can be passive technicians, reflective practitioners or transformative intellectuals. A teacher who acts as a passive technician primarily sees teaching as a practice to transmit pieces of knowledge from the "expert" (the teacher) to the "apprentices" who are considered "empty boxes" and must reproduce the information exactly as they received it. The teacher's role is as a conduit promoting learner's comprehension and reproduction of content knowledge.

Next, a teacher who performs the role of a reflective practitioner comprehends that his/her practice is continuously evolving through reflection based on 
content knowledge and experiences. $\mathrm{He} / \mathrm{she}$ acts as a facilitator. As Dewey (cited by Westbrook 1993) claimed "teaching is seeing not just as a series of predetermined and pre-sequenced procedures but as a context-sensitive action grounded in intellectual thought". Finally, a transformative intellectual is a teacher who is inquiry oriented, socially contextualized, an improviser, committed, sensitive, concerned, able to be self-contextualized and a generator of theories. He acts as an agent of change. As consequence, language teachers need to consider themselves as potential creators of local knowledge, because they have the professional and the personal knowledge of the context and learners' needs. They know the characteristics, the functioning of teaching and learning practices, and the environment where these practices are produced and carried out. Local knowledge refers to the understanding a person has about his context, acquired through the experience and contact with the reality. According to Freire and Faundez (2013), the objective is:

To propose knowledge sensible to local ideals, dreams, aspirations and necessities. Knowledge to integrate not to ignore others, imposing them the kind of generalized knowledge that one wants to teach. Knowledge, which do not disregard the particularities but highlight them (p. 84).

\section{From method to postmethod}

Some Language teachers affirm that it is relevant to apply the principles of a method to orient the FL teaching and learning practices. However, most of them do not take into account the significant limitations that the method can offer place in the learning process in order to make certain decisions that can be more appropriated and favorable considering the particularities of the context and learners where it is applied. Moreover, in many occasions teachers' actions are not coherent with the different steps and aspects that a method considers. According to Kumaravadivelu (2003),

teachers seem to be convinced that no single theory of learning and no single method of teaching will help them confront the challenges of everyday teaching. They use their own intuitive ability and experiential knowledge to decide what works and what does not work (p. 166).

Methods are conceived in order to be applied according to general pedagogical assumptions, which do not take into account particular characteristic or differences but instead focus on standard principles as bases to work with. For that reason, teachers are expected to make them pertinent through contextualization adapting them and not just applying them as recipes.

The objective is to take advantage of the principles that perfectly match a specific context. Freire and Faundez (2013) refer to methods as: 
A set of principles that must be constantly recreated, to the extent that the reality, other and always different, demands that those principles be read in a different way and enriched in a diverse way...The method is a kind of provocation to intellectuals and to the reality for recreating it, with the aim to translate the methodological principles according to the demands and to respond, in this way, to the different concrete realities (p. 62-63)

Here is a comparison of some of the differences between method and post method pedagogy. Some of them are shown in the following table:

Table 1. Method and post method differences based on Kumaravadivelu (2006)

\begin{tabular}{|l|l|}
\hline \multicolumn{1}{|c|}{ Method } & \multicolumn{1}{c|}{ Post method } \\
\hline $\begin{array}{l}\text { - Created for global consumption. } \\
\text { - A particular view of the world }\end{array}$ & - Considering our own context and \\
- Too scholastic & validate local knowledge (Particularity) \\
- Monolingual tenet & Potencialize the use of L1. \\
- The individual voice is marginalized, it & Enhance the relationship between \\
is prescriptive & language and thinking development. \\
& - Relates theory and practice. (Practicality) \\
\hline
\end{tabular}

Considering a post method condition implies making a clear and coherent balance between teachers' professional knowledge and the different experiences they have acquired through their practice in a specific context. These aspects are considered under the three pedagogic parameters of the post method pedagogy proposed by Kumaravadivelu (2003): practicality, particularity and possibility. Particularity considers the individual and specific characteristic of the context and learners with the aim to create pertinent and significant goals, activities, procedures and outcomes. Besides, practicality is understood as the balance between theory and practice where teachers are builders of local knowledge and not passive consumers of theories. Finally, possibility offers the learner the possibility to participate in the construction of the teaching and learning practices nurturing the curriculum and the pedagogical process with their experiences, values and visions.

\section{Considerations for Decolonizing Teaching Practices}

When teachers ask themselves what kind of instruction makes a difference, it is necessary to have plenty of knowledge about the characteristics of the context considering our students' needs and interests, in order to create pertinent goals and outcomes that guide them to make the necessary modifications to transform the curriculum into a coherent one. 
Besides, it is of paramount importance that teachers gain awareness of certain kinds of colonizing ideas that have been implemented inside their minds as a product of their formation and educational policies. These policies have been introduced through different discourses in order to favor standardized models as the Common European framework. According to Quintero and Guerrero (2013), “... teachers position themselves as the ones who know about the context but lack the power to make their voices heard" (p. 201).

Language is a whole; it is not just the production of coherent- grammatical forms, but the ability to use them in different ways instead, providing the opportunity to explore the world and human relationships through language. In spite of that important use of language, teachers tend to give a lot of importance to language form and little space for language practice, interaction and reflection. Why? Maybe because they were taught English using a grammatical method where learning correct forms of language was the desirable goal and now they use the same method to teach their students. Therefore, it is vital for teachers to try to explore different practices inside their classrooms so they set varied and meaningful goals for students and give themselves the opportunity to learn from learners as well. As a matter of fact, as much as possible, teachers should provide opportunities for interaction and meaning negotiation, for instance, through problem- solving activities.

One of the actions teachers can do in order to decolonize their teaching practices is to involve their students' experiences and voices including different reflective activities into the syllabus. Kumaravadivelu (2003) states, "decolonization is a fairly complex process of taking control of the principals and practices of planning, learning and teaching English" (p. 540). In this regard, the beginning of a decolonization process involving teaching practices needs to consider gaining awareness of what decolonization implies. Secondly, it should consider to understand that it is a process and requires time and recognition of what everyone does in and out of the classroom to strengthen meaningful learning and decision making regarding planning and teaching. Thirdly it requires to propose and design a theory from one's practice.

Another action is the need to develop a sense of awareness among teachers and students about being able to adopt a critical and positive position, in order to know how to assess all the contents and information received through different sources. It implies that learners have to do more than the basic instructions to work in an activity, developing their "high order thinking skills" (Bloom's taxonomy) and adopting a personal position in front of what they are daily exposed to; mainly, in this time period in which the access 
to information is available everywhere and for everybody. For instance, students should be asked in their language classes, not only to reproduce general or specific details about a text, but also to express opinions, identify social, cultural, political, historical influences inside a text and discussing crucial issues with their group.

English teachers are charge with not only showing cultural, social, economic, educational and political aspects through the foreign language learning, but also, assuming the role to provoke students' reactions to their own conceptions, while at the same time encouraging them to examine their identity. This can be done by guiding students to learn about their cultural values as they participate in collaborative reflection inside classrooms. Mclaren et al (2008) states:

...More than to acquire teaching methods, teachers and leaders of education engaged with the critical pedagogy are also aware of the social, economic, psychological dimensions and policies of the school and the region, the systems in which they develop their tasks. Also, they have a wide range of knowledge about the information systems that, in a wider cultural framework act as pedagogical forces in the learners lives (p. 35).

Bearing the previous in mind, it is necessary to approach and to transform the curriculum taking into account students' lives experiences and interests and to avoid trying to make students fit into a designed syllabus, in which the mayor priority is to achieve a desired standard. Students have to participate in curricular development and be active participants of their own learning process.

\section{General Organization of Proposal}

The context has a great influence in the foreign language learning process. The national education policies for example promote FLL through the bilingualism program (Colombia very well) giving some reasons and orientations to learn English, which are totally different from the desired context in which those public policies are standardized. These are not connected to the local context realities and needs as the principle of particularity demands. The current proposal was created for a group of beginners in a public technical institution in Boyacá. There, the point of view of people about foreign language learning (FLL) is totally different. Teachers have to find ways to engage students through language learning, giving them another reasons to learn which are not those of national policies, because most of them come from families where using a FL has not been necessary to survive.

The language opportunities of these learners are limited to the spaces created in English class which are very restricted in comparison to the exposure they would need to have in order to quickly acquire the language. Whereupon it is necessary to encourage 
their attitude and motivation through English class, involving them to participate in different activities which demand students' interaction, giving them the chance, not only to develop their communicative competence, but also to develop thinking skills so they can adopt a critical position about what is going on around them, in their context and what they know.
In the following chart the reader can observe the description of a modified lesson plan which was based only on the basic knowledge students should learn according to a textbook provided by the bilingual program for some public schools. The left column includes the modifications and the right column exhibits the original plan.

Table 2. Initial lesson plan adaptations

\begin{tabular}{|c|c|}
\hline Proposed lesson plan & $\begin{array}{c}\text { Lesson plan proposed by the school } \\
\text { considering the text book }\end{array}$ \\
\hline $\begin{array}{l}\text { Standards } \\
\text { - I read and propose new ways of presenting } \\
\text { the acquire knowledge. } \\
\text { I interact with my classmates and the teacher } \\
\text { about the topic of interest. } \\
\text { I give my points of view participating } \\
\text { actively in the conversations presented in the } \\
\text { classroom } \\
\text { I plan, carry out and share the interview } \\
\text { findings that I develop and apply. } \\
\text { I am able to propose and reflect upon the } \\
\text { findings. }\end{array}$ & $\begin{array}{l}\text { Standars } \\
\text { - Sigo instrucciones dadas en clase para realizar } \\
\text { actividades académicas [I follow instructions } \\
\text { given in class to develop activities] } \\
\text { Entiendo lo que me dicen el profesor y mis } \\
\text { compañeros en interacciones cotidianas } \\
\text { dentro del aula sin necesidad de repetición. } \\
\text { [I understand what the teacher says and my } \\
\text { classmates in daily interactions inside the } \\
\text { classroom without the necessity of repetition] } \\
\text { Identifico la recurrencia de ideas en un mismo } \\
\text { texto [I identify the recurrence of ideas in a } \\
\text { text] } \\
\text { Participo en una conversación cuando mi } \\
\text { interlocutor me da tiempo para pensar en mis } \\
\text { respuestas. [I participate in a conversation } \\
\text { when my interlocutor gives me time to think } \\
\text { in my answers] } \\
\text { Hago exposiciones ensayadas y breves sobre } \\
\text { algún tema académico de mi interés [I develop } \\
\text { prepared and brief presentations about some } \\
\text { academic topics of my interest] } \\
\text { Diligencio efectivamente formatos con } \\
\text { información personal [I fill formats with } \\
\text { personal information] }\end{array}$ \\
\hline
\end{tabular}




\begin{tabular}{|c|c|}
\hline Topic: UNIT 6. Tech Time, Present continuous & $\begin{array}{l}\text { Topic: UNIT 6. Tech Time, Present } \\
\text { continuous }\end{array}$ \\
\hline \begin{tabular}{|l|} 
Objectives: \\
To identify the use of technology establishing \\
- $\quad$ relations with his/her daily life experiences. \\
excessive use of technology \\
- To reflect on technology management and \\
propose some recommendations
\end{tabular} & $\begin{array}{l}\text { Objectives: } \\
\text { Maneja vocabulario relacionado con } \\
\text { dispositivos electrónicos, actividades de } \\
\text { tiempo libre e intereses. [To use vocabulary } \\
\text { related to electronic devices, free time } \\
\text { activities and interests] } \\
\text { Describe actividades cotidianas. [To describe } \\
\text { daily activities] } \\
\text { Emplea correctamente el tiempo presente } \\
\text { simple en sus diferentes formas. [To use } \\
\text { simple present tense in its different forms in } \\
\text { a proper way] }\end{array}$ \\
\hline Time frame: 8 hours & Time frame: 2 hours \\
\hline $\begin{array}{l}\text { Activities: Activities are organized in which } \\
\text { students can have the opportunity to work on } \\
\text { their different skills. } \\
\text { 1. The teachers are going to organize the } \\
\text { classroom in a round table and they are going } \\
\text { to write a question in which students will have } \\
\text { to reflect and think about why technology is } \\
\text { an important part of their free time? Writing } \\
\text { 2. Afterwards, they will try to connect students } \\
\text { with the topic through the following } \\
\text { questions: Speaking } \\
\text { - How many of you use a laptop, mobile, a } \\
\text { DVD, music player, computer, games console, } \\
\text { television, camera or tablet. } \\
\text { How often do you use them? } \\
\text { Why do you use them (chatting, checking, } \\
\text { listening, playing, sending, taking going, and } \\
\text { watching)? } \\
\text { 3. Then, students are going to watch a video } \\
\text { about technology addiction; they will have } \\
\text { to identify some of the risks related to the } \\
\text { excessive use of technology. Listening } \\
\text { 4. Considering the previous exercise, students } \\
\text { have to share their understandings or } \\
\text { reflections in regards to the video. They are } \\
\text { going to create a poster as means to elaborate } \\
\text { in a cooperative way a poster display, } \\
\text { considering some other information they } \\
\text { think is important. Reading } \\
\text { 5. They are going to read the posters of their } \\
\text { classmates and identify the most creative and } \\
\text { reflective one. } \\
\text { 6. After that, students are going to create } \\
\text { different questions for people around them } \\
\text { asking about the use, risks and management } \\
\text { of technology. It would be an interview } \\
\text { created by students. Writing } \\
\text { 7. Then, students will share their findings } \\
\text { through a power point presentation to the } \\
\text { class. Speaking } \\
\text { 8. Based on the findings, students will } \\
\text { identify some key ideas to propose some } \\
\text { recommendations about the management } \\
\text { of technology and post them inside the } \\
\text { classroom. Writing }\end{array}$ & $\begin{array}{l}\text { Activities: Activities are organized in which } \\
\text { students can have the opportunity to work on } \\
\text { their different skills. } \\
\text { 1. Contestar la siguiente pregunta [Answer } \\
\text { the following questions]: is technology an } \\
\text { important part of your free time? Writing } \\
\text { 2. Mathing: nombres de aparatos electrónicos y } \\
\text { sus respectivas imágenes. [Name of electronic } \\
\text { devices and their images] Reading } \\
\text { 3. Identificar verbos y hacer oraciones sobre } \\
\text { actividades relacionadas con el uso de la } \\
\text { tecnología. [Identify verbs and do sentences } \\
\text { related to the use of technology] Writing } \\
\text { 4. Identificar la pronunciación de la vocal "a" } \\
\text { [Identify the pronunciation of the vowel "a"] } \\
\text { Listening } \\
\text { 5. Formar oraciones sobre los aparatos } \\
\text { electrónicos y su uso. [Form sentences about } \\
\text { electronic devices and their use] Writing } \\
\text { 6. Escuchar a cinco jóvenes hablando sobre } \\
\text { una herramienta tecnológica e identificarla. } \\
\text { [Listen to five young people talking about a } \\
\text { technological tool and identify it] Listening. } \\
\text { 7. Practicar en una conversación preguntas y } \\
\text { respuestas usando }(i \text { have / we have.... at homee } \\
\text { my brother / my mom has/ } i \text { used it to/ } i \text { 'd like } \\
\text { a...) [Practice in a conversation questions and } \\
\text { answers using (I have / we have .... At home / my } \\
\text { brother / my mom has / i used it to / I would like to } \\
\text {..)] Speaking } \\
\text { 8. Dibuja tu herramienta tecnológica favorita y } \\
\text { descríbela en cuatro oraciones. [Draw your } \\
\text { favorite technological tool and describe it in } \\
\text { four sentences] Writing } \\
\text { 9. Comparte tu descripción con un compañero } \\
\text { y grábala con el objetivo de publicarla en la } \\
\text { web. [Share your description with a classmate } \\
\text { and record it in order to publish it on the web] } \\
\text { Speaking }\end{array}$ \\
\hline
\end{tabular}




\begin{abstract}
Products
Small posters with key aspects of recommendations about the risks and management of technology to paste them around the classroom. Posters will be according to students' perceptions on what they consider important about the risk and management of technology.
\end{abstract}

\section{Extra improvement} Activities

Create a brochure about the use, risks and management of technology in daily life.
Actividades de apoyo y superación [support and overcoming activities]

Elabore un poster describiendo en cinco oraciones su herramienta tecnológica favorita. Apoye con un dibujo. [Make a poster describing in five sentences your favorite technological tool. Support with a drawing]

The proposed material for the development of decolonizing practice is different in every stage of the class. First, teachers are going to use some pieces of paper with questions such as: "is technology an important part of your free time? How many of you use a laptop, mobile, a DVD, music player, computer, games console, television, camera and Tablet? How often do you use them? Why do you use them (chatting, checking, listening, playing, sending, taking, going, and watching)?"

Next, teachers are going to use laptop, a projector and speakers for presenting a video called "technology addiction". And then, they will provide different sheets of paper for creating posters in relation to the video. After that, they will be interviewed through some questions created by students about the risks and management of technology. Then, a power point presentation will be delivered considering findings in regards to the applied survey. Finally, markers and pieces of paper are provided for students to write key aspects about the risk and management of technology.

\section{Conclusions}

Teaching practices are becoming more difficult every day. School principals tell teachers what to do and how to teach students with a heavy focus on textbooks. In addition, some teachers have fossilized teaching practices that they use with all students every year without being aware of their needs and background. Another aspect that contributes to the problem is that education has become an invisible problem for the Ministry of education in Colombia.

However, despite all the different circumstances that English teachers face every single day, it is clear that this is a matter of making informed decisions for taking control of suitable principles and practices in learning, teaching and planning. Teachers have to take an active role in what they do since they are the ones who know students and work directly with them.

The pedagogical proposal to start decolonizing teaching practices was a reflection activity about teachers' role in teaching, not just as knowledge facilitators, but also as change agents. 
Educators are not just theory consumers, they need to take an active and positive attitude towards the transformation of a curriculum that includes students' needs and interests. It was a first step in a long process of identifying what is worth for students and what they really have to be aware of, since they are citizens that belong to a community that expects them to assume critical positions on what is going on around them.

\section{References}

Antony, E. M. (1963). Approach, method, technique. English Language Teaching. (p. 63-64).

Carvajal, N, E. (2011). Teaching, Learning and Assessment: Isolated practices? Enletawa Journal. Maestria en Docencia de Idiomas.

Freire, P. and Faundez, A. (2013). Por una Pedagogía de la Pregunta. Crítica a una educación basada en respuestas a preguntas inexistentes. Buenos Aires. Grupo Editorial Siglo XXI, pp. 66-160. Authors' translations

Feiman-Nemser, S., and Floden, R.E. 1986. The cultures of teaching. In M.C. Wittrock (ed.), Handbook of Research on Teaching, 3rd ed. New York: Macmillan. pp. 50526.

Halliday, M.A.K. ( 1979 ). El Lenguage como Semiótica Social. La interpretación social del lenguaje y del significado. México. Fondo de Cultura Económica.

Halliday, M.A.K. (1973 ). Explorations in the functions of Language. London. Arnold.

Kroskrity, P. V. (2000). Regimenting languages: Language ideological perspectives. In P. V.
Kiroskrity (Ed.), Regimes of language (pp. 1-34). Santa Fe, NM: School of American Research Press.

Kumaravadivelu, B. (2003) Beyond methods: micro-strategies for language teaching. Yale University press. 5-42.

Kumaravadivelu, B. (2006) Understanding Language Teaching. From method to Postmethod. ESL and Applied Linguistics Professional Series. San Jose State University.

Mckay, S. (2002) Teaching English as an international Language: Rethinking goals and perspectives. Ney York University Press. June 2003, Vol 7, number 1.

Mclaren, P. and Kincheloe J. (2008) Critical Pedagogy: where are we know? Barcelona. Colección Crítica y Fundamentos.

Pass, S. (2004). Parallels paths to Constructivism. Jean Piaget and Lev Vigostsky. Library of Congress cataloging in publication Data. United States of America.

Programa Nacional de bilingüismo Colombia 2004-2019. Inglés como lengua extranjera, una estrategia para la competitividad. Ministerio de Educación Nacional.

Quintero, A. y Guerrero, C. (2013) "Of being or not being". Colombian Public Elementary School Teachers' Oscillating Identities. Bogotá. How Journal, 20 (1), 201.

Sánchez, J. A. (2013) Bilingüismo en Colombia. Centro de estudios Económicos Regionales. Banco de la República. Cartagena de indias, Colombia.

Westbrook, R (1993) John Dewey and American democracy. Ithaca, Cornell Universiry Press. 


\section{Annexes}

Annex A: Lesson plan proposed by the school considering the English Text book.

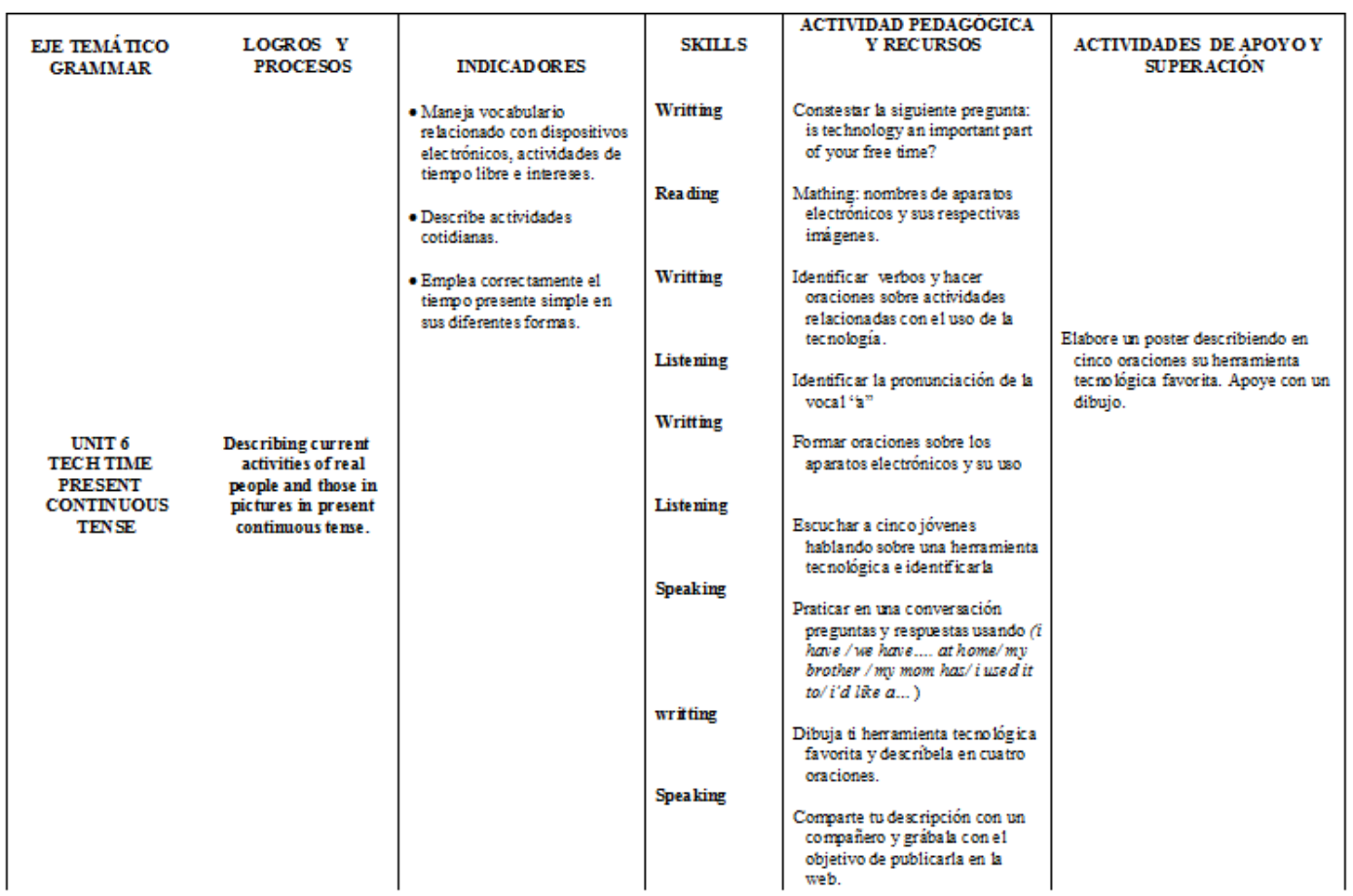


Annex B: Lesson plan proposed by the Master Students.

\begin{tabular}{|c|c|c|c|c|c|}
\hline $\begin{array}{l}\text { EJE TEMÁTICO } \\
\text { GRAMMAR }\end{array}$ & $\begin{array}{l}\text { LOGROS Y } \\
\text { PROCESOS }\end{array}$ & INDICADORES & SKIILS & ACIIVIDAD PEDAGOGCA Y RECURSOS & $\begin{array}{l}\text { ACTIVIDADES DE } \\
\text { APOYOY } \\
\text { SUPERACIÓN }\end{array}$ \\
\hline $\begin{array}{c}\text { UNIT } 6 \\
\text { TECH TDIE } \\
\text { PRESENT } \\
\text { CONIINUOUS }\end{array}$ & $\begin{array}{l}\text { Reflecting upou the } \\
\text { use, risks and } \\
\text { management of } \\
\text { technology in order to } \\
\text { propose some } \\
\text { recommendations } \\
\text { about its use. }\end{array}$ & $\begin{array}{l}\text { - Identify the use } \\
\text { of technology } \\
\text { establishing } \\
\text { relations with } \\
\text { his her deily life } \\
\text { experiences }\end{array}$ & $\begin{array}{l}\text { Writting } \\
\text { Speaking } \\
\text { Writting }\end{array}$ & 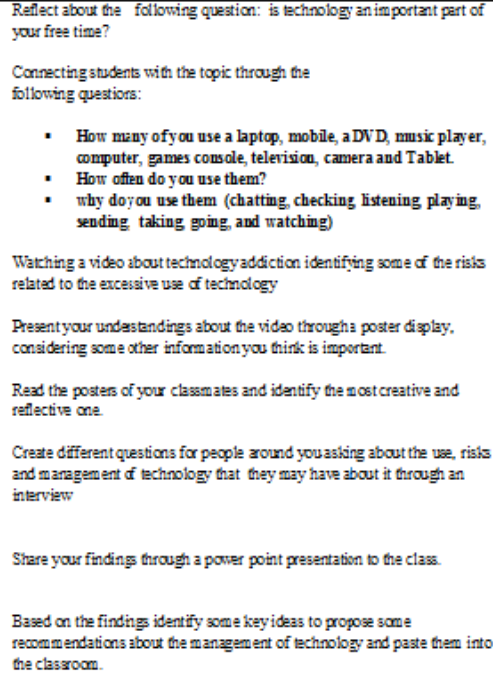 & $\begin{array}{l}\text { Craate a brochure } \\
\text { about the use, risks } \\
\text { and management of } \\
\text { technology in daily } \\
\text { life. }\end{array}$ \\
\hline
\end{tabular}

